\title{
ANTIDIARRHEAL ACTIVITY OF ETHANOLIC EXTRACT OF Vernonia amygdalina Del LEAVES AGAINTS MALE MICE INDUCED BY OLEUM RICINI
}

\section{Karunita Ika Astuti* \\ Lusiana Dwi Wulandari \\ Eka Fitri Susiani}

Sekolah Tinggi Ilmu Kesehatan Borneo Lestari, Banjabaru, South Kalimantan, Indonesia

email: karunitaika@gmail.com

\section{Keywords:}

Antidiarrheal

Oleum ricini

Vernonia amygdalina DeL. leaves

\begin{abstract}
Leaves of Vernonia amygdalina Del. is one of the alternative plants that people use as antidiarrheal in Martapura, Banjar. The purpose of research to determine the antidiarrheal activity and the effectiveness of ethanolic extract of leaves against male mice. The negative control was given NaCMC $0.5 \%$ orally, positive control was given Loperamide $\mathrm{HCl} 0.005$ $\mathrm{mg} / 20 \mathrm{~g}$ orally, and groups of ethanolic extract of leaves were given dosages in $100 \mathrm{mg} / \mathrm{kg}$ BW, $200 \mathrm{mg} / \mathrm{kg} \mathrm{BW}$, and $400 \mathrm{mg} / \mathrm{kg} \mathrm{BW}$ orally. After I hour of treatment, the groups were induced by Oleum ricini orally and were observed for 4 hours. Based on three parameters were frequency, weight, and consistency of diarrhea. From the results observation of that negative control, positive control, EEDA $100 \mathrm{mg} / \mathrm{kg} \mathrm{BW,} 200 \mathrm{mg} / \mathrm{kg}$ $B W$, and $400 \mathrm{mg} / \mathrm{kg} B W$ for diarrhea frequency parameter was $7.4 \pm 2.30 ; 2 \pm 1.22 ; 5.8$ $\pm 3.34 ; 6.2 \pm 4.08 ; 2.4 \pm 1.67$; the weight parameter was $1.34 \pm 0.43 ; 0.38 \pm 0.29 ; 0.66$ $\pm 0.56 ; 0.57 \pm 0.38 ; 0.49 \pm 0.33$ and then consistency of diarrhea with EEDA $400 \mathrm{mg} / \mathrm{kg}$ $B W$ improved the consistency at 180 minutes compared to control group at 210 minutes. In conclusion, from all parameters of ethanolic extract of Vernonia amygdalina Del. leaves can give an antidiarrhea effect with optimum dosage is $400 \mathrm{mg} / \mathrm{kg} \mathrm{BW}$.
\end{abstract}

(C) 2019 The Authors. Published by Institute for Research and Community Services Universitas Muhammadiyah Palangkaraya. This is Open Access article under the CC-BY-SA License (http://creativecommons.org/licenses/by-sa/4.0/). DOI: https://doi.org/10.33084/bjop.v2il.707.

\section{INTRODUCTION}

Diarrhea is still a global problem and is one of the main causes of high child morbidity and mortality in the world (Nurhalimah et al., 20I5). In general, it is estimated that more than 10 million children aged less than 5 years die every year, around $20 \%$ die of diarrhea. Diarrhea is still a public health problem in developing countries such as Indonesia (Ministry of Health of the Republic of Indonesia, 2014). The presentation of diarrhea in Indonesia was 6,897,463 cases per year (Ministry of Health of the Republic of Indonesia, 2016).

The use of traditional medicines is increasingly growing and tends to be favored by many people because it has many advantages, including relatively cheap prices, easily obtained raw materials and side effects of traditional medicines which are considered smaller than the side effects of synthetic drugs. One of the plants that can be used as traditional medicine is Vernonia amygdalina Del. or african leaves. Vernonia amygdalina Del. grow in the west, especially in tropical countries like Indonesia (Suryati et al., 2016). Currently, there is no research related to $V$. amygdalina as antidiarrheal. Vernonia amygdalina Del. are empirically used by the community of South Kalimantan, especially in the Martapura district of Banjar as an antidiarrhe with simple processing by drinking V. amygdalina decoction (Kharimah et al., 20l6). From the description above, the authors would like to conduct further research with the aim of relating extraction of $V$. amygdalina as antidiarrheal and increasing knowledge and information about $V$. amygdalina as antidiarrheal.

\section{MATERIAL AND METHODS}

\section{Tools and Materials}

The materials used in this study were leaves of $\mathrm{V}$. amygdalina, 96\% ethanol, Loperamide $\mathrm{HCl}$, aquadest, oleum ricini, Sodium-carboxy methyl cellulose ( $\mathrm{Na}$ CMC) $0.5 \%$, acetic acid, magnesium powder, $1 \% \mathrm{FeCl}$, $\mathrm{HCl}$ concentrated, Mayer reagent, Liebermen-Burchard reagent and Wagner reagent.

The tools used are rotary evaporator, stopwatch, analytical scales, and oral sonde. The study used test animals of male Balb / C strain with a weight of 20-30 grams and aged 2-3 months. Ethical clearance is 
obtained from Health Research Ethics Commission, Faculty of Medicine, Universitas Lambung Mangkurat Indonesia with number 793/KEPK-FK UNLAM/EC/VII/20I8.

\section{Methods}

\section{Extraction}

Vernonia amygdalina leaves dried and pollinated, then weighed as much as $200 \mathrm{~g}$. The powder was macerated with ethanol $96 \%$ as much as $\mathrm{I} L(I: 5)$ at room temperature or protected from direct sunlight for I $\mathrm{x}$ 24 hours extract was collected and the residue macerated. Furthermore, macerated $3 \times 24$ hours, the results of maceration were then concentrated with a rotary evaporator and waterbath at $60^{\circ} \mathrm{C}$ to obtain a thick extract.

\section{Phytochemical Screening}

Phytochemical Screening with reagents to determine the content of Vernonia amygdalina leaves. The groups of compounds tested included alkaloids, flavonoids, steroids, saponins, and tannins.

\section{Alkaloid Test}

A total of $0.5 \mathrm{~g}$ of extract was added with 10 drops of $2 \mathrm{~N}$ sulfuric acid shaken until two layers were formed. The top layer is divided into 2 parts in the test tube. The first tube is added to the Mayer reagent, white deposits will form. The second tube was added to Wegner's reagent, brown deposits will form (Lailatul et al., 2010).

\section{Flavonoid Test}

A total of $0.5 \mathrm{~g}$ of extract was put into a test tube. The filtrate is added 2-3 drops of concentrated sulfuric acid and $0.2 \mathrm{~g}$ of Magnesium powder, then shake vigorously. Changing the color of the solution to orange to brick red indicates the presence of flavonoids (Noer et al., 2018).

\section{Steroid Test}

A total of $0.5 \mathrm{~g}$ of extract was put into a test tube, then added 10 drops of anhydrous acetic acid, 2 drops of concentrated sulfuric acid, and several LiebermanBurchard reagents. The solution is shaken slowly and left for a few minutes. The presence of steroids is shown in blue or green (Lailatul et al., 2010).

Saponin Test

A total of $0.5 \mathrm{~g}$ of extract is put into a test tube, then 2 $\mathrm{mL}$ of water is added and shaken vigorously for 10 seconds. The presence of saponins is indicated by the formation of stable foam for 10 minutes with height of I-3 cm (Noer et al., 20I8).

Tannin Test

A total of $0.5 \mathrm{~g}$ of extract is put into a test tube, then were added by 2 or 3 drops of $1 \% \mathrm{FeCl}_{3}$ solution. The blackish green or dark blue solution formed indicated the precence of tannins (Noer et al., 2018).

Antidiarrheal Activity Test

Test animals were divided into five groups consisting of five mice adapted and fasted for one hour before treatment. Furthermore, each group was treated orally consisting of a control group (0.5\% $\mathrm{Na}-\mathrm{CMC})$, a test group with extracts (100, 200 and $400 \mathrm{mg} / \mathrm{kg} \mathrm{BW})$, and a comparison of Loperamid $\mathrm{HCl}(0.005 \mathrm{mg} / \mathrm{kg} \mathrm{BW})$. After that all test animals were given induction of Oleum ricini $0.75 \mathrm{ml}$ orally. After the test animals were treated, four hours of observation were carried out with the observed parameters including diarrhea frequency, faecal weight and stool consistency.

\section{Data Analysis}

Data from stool consistency observation, diarrhea frequency and faecal weight were tested statistically with variance analysis method at $95 \%$ confidence level, followed by One Way ANOVA SPSS version 19.0.

\section{RESULTS AND DISCUSSION}

\section{Extraction}

Of the $200 \mathrm{~g}$ of $V$. amygdalina leaf powder, $31.43 \mathrm{~g}$ of thick ethanol extract was obtained with the extract yield of $15.67 \%$. 


\section{Phytochemical Screening}

Phytochemical screening is a qualitative test which aims to determine the active compound content of secondary metabolites in plant extracts. Phytochemical screening tests showed positive results for all tested components, namely alkaloids, flavonoids, steroids, saponins, and tannins. The test results can be seen in Table I.

Table I. Phytochemical screening results of ethanol extract from $V$. amygdalina leaves

\begin{tabular}{lllc}
\hline $\begin{array}{c}\text { Compound } \\
\text { groups }\end{array}$ & Reagent & Reaction results & Description \\
\hline Alkaloid & Mayer & White precipitated & + \\
& Wegner & Brown precipitated & + \\
Flavonoid & Mg metal & Brick red solution & + \\
Steroid & Lieberman- & Greenish solution & + \\
& Burchard & & \\
Saponin & Water & Foam & + \\
Tanin & I\% FeCl & Blackish green & + \\
\hline
\end{tabular}

\section{Antidiarrheal Activity Test}

Testing this antidiarrheal activity uses a protection method. In the protection method oleum ricini is used as the inducer. Oleum ricini or castor oil is a triglyceride that is efficacious as laxansia. In the small intestine, this oil undergoes hydrolysis and produces risinoleic acid which stimulates the intestinal mucosa, thereby accelerating its peristalsis and resulting in rapid bowel evisceration, in the form of dilute discharge of bowel movements (Guo et al., 20l4). Determination of antidiarrheal activity of ethanol extract of $V$. amygdalina leaves was carried out by observing the frequency of diarrhea, consistency, and weight of faeces

\section{Frequency of Diarrhea}

The first parameter observed in the protection method induced by oleum ricini was the frequency of diarrhea. Where in determining the frequency of diarrhea, obtained the average value of each group of negative control showed a significant difference $(p<0.005)$ to Loperamid $\mathrm{HCl}$ and extract of $400 \mathrm{mg} / \mathrm{kg} \mathrm{BW}$, while extracts of $100 \mathrm{mg} / \mathrm{kg} \mathrm{BW}$ and extracts of $200 \mathrm{mg} / \mathrm{kg}$ BW shows differences that are not significantly different ( $p>0.005$ ). This shows that Loperamid $\mathrm{HCl}$ and extract of $400 \mathrm{mg} / \mathrm{kg}$ BW can prevent diarrhea significantly better than extract $100 \mathrm{mg} / \mathrm{kg} \mathrm{BW}$ and extract 200 $\mathrm{mg} / \mathrm{kg}$ BW. The average frequency of diarrhea can be seen in Table 2.

Table 2. Average Frequency of Diarrhea

\begin{tabular}{lcc}
\hline \multicolumn{1}{c}{ Test Group } & Dosage $(\mathrm{mg} / \mathrm{kg} \mathrm{BW})$ & Frequency \pm SD \\
\hline Negative Control & - & $7.4 \pm 2.30$ \\
Loperamide HCL & 0,005 & $2 \pm 1.22^{*}$ \\
Ethanol extract of & 100 & $5.8 \pm 3.34$ \\
V. amygdalina & 200 & $6.2 \pm 4.08$ \\
leaves & 400 & $2.4 \pm 1.67^{*}$ \\
\hline
\end{tabular}

Description: $0.5 \% \mathrm{Na}$-CMC Negative Control; * Significantly different $\mathrm{P}(<0.05)$ with controls

\section{Stool Consistency}

The next parameter observed was stool consistency as can be seen in Figure I. The consistency of faeces was determined from the start of being given induction of Oleum ricini until the occurrence of diarrhea, which was observed every 30 minutes for four hours. In determining the consistency of faeces done by looking at the shape that occurs it can be categorized into four groups, namely not chapter (0), normal (I), soft (2), and slimy/watery (3). Consistency seen visually was assessed using Scoring, so that groups that were declared to have antidiarrheal effects were the group that showed the smallest consistency rate (Suherman et al, 2013).

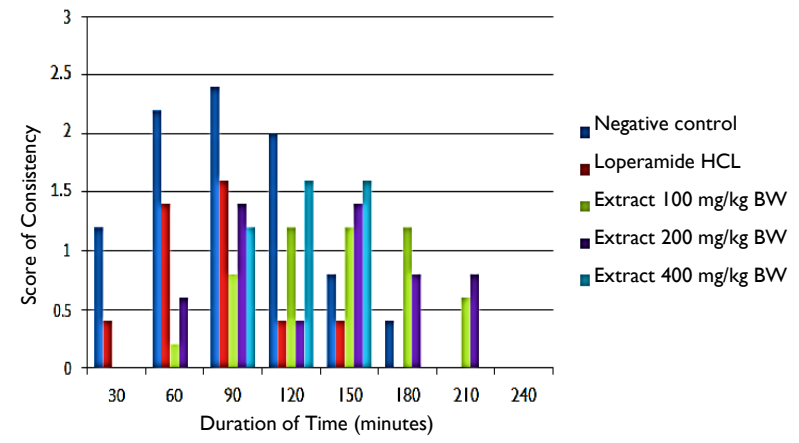

Figure I. Stool consistency per time

In Figure I shows that Loperamide $\mathrm{HCl}$ improves stool consistency at minute 150; extract $100 \mathrm{mg} / \mathrm{kg}$ BW improves stool consistency at 210 minutes; extract 200 $\mathrm{mg} / \mathrm{kg}$ BW improves stool consistency at 180 minutes; extract of $400 \mathrm{mg} / \mathrm{kg}$ BW improved stool consistency in the $150^{\text {th }}$ minute compared to the negative control 
group. The smaller the number of stool consistency, the greater the antidiare effect produced (Suherman et al., 20I3). The results of the study of ethanol extract of the leaves of $V$. amygdalina $400 \mathrm{mg} / \mathrm{kg}$ BW which have the best effect as antidiarrheal are associated with a corresponding increase in dosage, the effect also increases (Nurhalimah et al., 20I5).

Stool Weight

The last parameter observed in the diarrhea protection method induced by oleum ricini was faecal weight to determine the presence or absence of antidiarrheal effects of the ethanol extract of the leaves of $V$. amygdalina. The average stool weight can be seen in Table 3.

Table 3. Average Stool Weight

\begin{tabular}{lcc}
\hline \multicolumn{1}{c}{ Test Group } & Dosage $(\mathrm{mg} / \mathrm{kg} \mathrm{BW})$ & Weight $(\mathrm{g}) \pm \mathrm{SD}$ \\
\hline Negative Control & - & $1.34 \pm 0.43$ \\
Loperamide HCL & 0,005 & $0.38 \pm 0.29^{*}$ \\
Ethanol extract of & 100 & $0.66 \pm 0.56$ \\
V. amygdalina & 200 & $0.57 \pm 0.38$ \\
leaves & 400 & $0.49 \pm 0.33^{*}$ \\
\hline
\end{tabular}

Description: $0.5 \% \mathrm{Na}-\mathrm{CMC}$ Negative Control; * Significantly different $\mathrm{P}(<0.05)$ with controls

The results showed that faecal weight showed a significant difference $(p<0.005)$ against Loperamide $\mathrm{HCl}$, extract $200 \mathrm{mg} / \mathrm{kg} \mathrm{BW}$ and $400 \mathrm{mg} / \mathrm{kg} \mathrm{BW}$ while extract $100 \mathrm{mg} / \mathrm{kg}$ BW showed no significant difference with negative controls. This shows that extract 200 $\mathrm{mg} / \mathrm{kg} \mathrm{BW}$ and extract $400 \mathrm{mg} / \mathrm{kg}$ BW can prevent diarrhea.

The results showed that the ethanol extract of leaves of V. amygdalina Del. at a dose of $400 \mathrm{mg} / \mathrm{kg} \mathrm{BW}$ is very good to use as an antidiarrheal because it contains secondary metabolites such as steroids, tannins, and flavonoids. The higher the dose, the better the activity as antidiarrheal because the extract used contains more secondary metabolites which have properties as antidiare. Steroid compounds as antidiarrhea can increase the absorption of water and electrolytes in the intestine, resulting in normal absorption of water and electrolytes in the intestine (Anas et al., 2012). Tannin in the sample can provide antidiarrheal activity (Tadesse et al., 2017). The mechanism of the tannin as an antidiarrheal is by shrinking the intestinal mucous membrane and shrinking the pore so that it will inhibit the secretion of excess electrolyte fluid (Tjay \& Rahardja, 2007). The mechanism of saponin as antidiarrheal by inhibiting histamine release which triggers a decrease in the absorption of fluids so that inhibition can normalize the absorption of fluids (Anas et al., 2012). The mechanism of flavonoids as antidiarrhea can inhibit intestinal motility, reduce the secretion of water and electrolytes and prolong intestinal transit time so that body fluids can be absorbed properly (Derebe et al., 2018).

\section{CONCLUSION}

The chemical compounds contained in the ethanol extract of leaves of $\mathrm{V}$. amygdalina positively contain flavonoids, steroids, tannins, saponins and alkaloids. There is an influence of giving the ethanol extract of leaves of $\mathrm{V}$. amygdalina to the frequency of stool (sig 0.040), stool consistency (sig 0.089) and stool weight (sig 0.07I). The results of the study of ethanol extract of leaves of V. amygdalina at a dose of $400 \mathrm{mg} / \mathrm{kg} \mathrm{BW}$ have an antidiarrheal effect.

\section{ACKNOWLEDGEMENTS}

The author would like to thank all colleagues and relatives who are pleased to give enthusiasm in completing this research and the entire research team and institutions of the Borneo Lestari College of Health Sciences as the place of research conducted.

\section{REFERENCES}

Anas, Y., Fitria, R.F., Purnamasari, Y.A., Ningsih, K.A, Noviantoro, A.G., Suharjono. 2012. Aktivitas Antidiare Ekstrak Etanol Daun Randu (Ceiba petandra L. Gaern.) pada Mencit Jantan Galur Balb/C. Jurnal Ilmu Farmasi \& Farmasi Klinik. $9(2): 16-22$ 
Derebe, D., Abdulwuhab, M., Wubetu, M., Mohammed, F. 2018. Investigation of the Antidiarrheal and Antimicrobial Activities of $80 \%$ Methanolic Leaf Extract of Discopodium Penninervum (Hochst.). BMC Complementary \& Alternative Medicine. 2018: I 360486.

Guo, Y., Niu, K., Momma, H., Kobayashi, Y., Chujo, M., Otomo, A., Fukudo, S., Nagatomi, R. 2014. Irritable bowel syndrome is positively related to metabolic syndrome: a population-based cross-sectional study. PLoS One. 9(II): el 12289.

Kharimah N. Z., Lukmayani, Y., Syafnir, L. 2016. Identifikasi Senyawa Flavonoid pada Ekstrak dan Fraksi Daun Afrika (Vernonia amygdalina Del.). Prosiding Farmasi. 2(2):703-709

Lailatul L.K., Kadarohman, A., Eko, R. 2010. Efektivitas Biolarvasida Ekstrak Etanol Limbah Penyulingan Minyak Akar Wangi (Vetiveria Zizanoides) Terhadap larva Nyamuk Aedes aegypti, cculex sp., dan Anopheles sundaicus. Jurnal Sains dan Teknologi Kimia. I(I):59-65.

Ministry of Health of the Republic of Indonesia. 20I4. Pengendalian Diare di Indonesia: Buletin Jendela Data dan Informasi Kesehatan. Jakarta: Ministry of Health of the Republic of Indonesia.

Ministry of Health of the Republic of Indonesia. 2016. Data dan Informasi: Profil Kesehatan Indonesia. Jakarta: Ministry of Health of the Republic of Indonesia.

Noer, S., Pratiwi, R.D., Gresinta, E. 2018. Penetapan Kadar Senyawa Fitokimia (Tanin, Saponin Dan Flavonoid Sebagai Kuersetin) Pada Ekstrak Daun Inggu (Ruta angustifolia L.). Eksakta: Jurnal Ilmu-ilmu MIPA. I8(I): 19-29.

Nurhalimah H. Wijayanti, N., Widyaningsih, T.D. 2015. Efek Antidiare Ekstrak Daun Beluntas (Pluchea indica L.) Terhadap Mencit Jantan Yang Diinduksi Bakteri Salmonella Typimurium. Jurnal Pangan dan Agroindustri. 3(3): 1083-1094.

Suherman, L.P., Hermanto, F., Pramukti, M.L. 20I3. Efek Antidiare Ekstrak Etanol Daun Midi (Melia azedarach Linn) pada Mencit Swiss Webster Jantan. Kartika: Jurnal IImiah Farmasi. I(I):3844.

Suryati S., Dillasamola, D., Rahadiantari, F. 2016. Pengaruh Ekstrak Etanol Daun Vernonia amygdalina Del. Terhadap Kadar Kreatinin Serum Mencit Putih Jantan. Jurnal Sains Farmasi dan Klinis. 3(I):79-83.
Tadesse, E., Engidawork, E., Nedi, T., Mengistu, G. 2017. Evaluation of the anti-diarrheal activity of the aqueous stem extract of Lantana camara Linn (Verbenaceae) in mice. BMC Complementary \& Alternative Medicine. 17:190.

Tjay, T. H., Rahardja, K. 2007. Obat-Obat Penting: Khasiat Penggunaan dan Efek-Efek Sampingnya. Jakarta: Elex Media Komputindo. 